\title{
Teacher Allocation and School Performance in Italy
}

Alex Bryson

Lorenzo Corsini

Irene Martelli

Quantitative Social Science

Working Paper No. 20-12

September 2020 


\section{Disclaimer}

Any opinions expressed here are those of the author(s) and not those of the UCL Social Research Institute. Research published in this series may include views on policy, but the institute itself takes no institutional policy positions.

QSS Workings Papers often represent preliminary work and are circulated to encourage discussion. Citation of such a paper should account for its provisional character. A revised version may be available directly from the author.

Quantitative Social Science

UCL Social Research Institute

University College London

\section{5-59 Gordon Square}

London WC1H 0NU 


\title{
Social Research Institute
}

\section{$\pm$

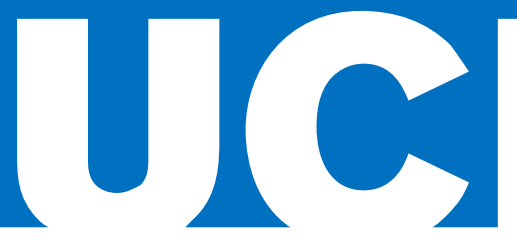

\section{Teacher Allocation and School Performance in Italy}

\author{
Alex Bryson ${ }^{1}$ \\ Lorenzo Corsini ${ }^{2}$ \\ Irene Martelli ${ }^{3}$
}

\begin{abstract}
Italy's secondary school system has faced funding constraints for many years which limits availability of new permanent job slots for teachers. When permanent posts do arise they are allocated mostly on seniority while merit only plays a small role. Thus, the age distribution of teachers in schools reflects older teachers' preferences which include the amenity of being close to urban centres. Using schools' distance from main urban centres and population size in the school's vicinity to instrument for non-random exposure of schools to older teachers, we show older teachers are detrimental to pupil attainment in secondary schools. The effect is large: a six-year increase in the average age of teachers (roughly similar to the increase that has occurred in the last 20 years) leads to a one standard deviation reduction in the mean graduation mark. The findings suggest there may be value in altering the way teachers are allocated to secondary schools in Italy.
\end{abstract}

Keywords pupil attainment; school performance; teacher allocation; teacher age; permanent contracts.

JEL Codes: J41; J44; J45 ; J48 ; J62 ; M51 ; M55

Acknowledgements: We thank participants at the Bank of Italy, Tuscany Branch, for useful comments on a previous version of this paper. Alex Bryson thanks the Economic and Social Research Council (grant ES/R00367X/1) for fundin

\footnotetext{
${ }^{1}$ University College London

${ }^{2}$ Corresponding author: Department of Economics and Management, University of Pisa, Via Ridolfi 10, Pisa, Italy. Iorenzo.corsini@unipi.it

${ }^{3}$ Sant'Anna School of Advanced Studies
} 


\section{INTRODUCTION}

Italy's education system has faced funding constraints for many years ${ }^{4}$ which limit the availability of new permanent job slots for teachers. Budget constraints mean schools tend to fill teacher vacancies using one-year fixed-term contracts. These are usually offered to new teachers, but these teachers cannot graduate from fixed-term contracts into a permanent position: the only way to obtain a permanent position is to be successful in national examinations. When permanent posts do arise they are allocated mostly on seniority while merit only plays a small role. Thus, the age distribution of teachers in schools reflects older teachers' preferences for the amenity of different types of school. Since wages are set nationally, this amenity value is captured along non-pecuniary dimensions of the job, such as the quality of pupils (and thus teacher workload) and the amenity value of a school based on its location.

In this paper we consider whether the system of filling permanent teacher vacancies based on older workers' preferences affects the quality of education pupils receive, as indicated by school-level pupil attainment. The issue is motivated by the concern that older teachers may be less productive than those from younger cohorts, either because their skills deplete with time due to a lack of onthe-job training; they lack the skills-set of their younger counterparts who benefit from recent innovations in teacher training; or because they lack the motivation to strive for teaching excellence (something younger teachers must do to secure permanent posts). ${ }^{5}$

We do not observe potential mechanisms. However, we exploit newly collected data on secondary schools in Italy which contains the age and seniority profile of teachers in each school, together with other school and teacher attributes, pupil examination performance and pupil entrance exam scores, from which we can construct school-level value added metrics.

We use the amenity value of schools based on their geographical distance from urban centres and population size in the vicinity of the school to identify the causal impact of non-random exposure to older teachers. We provide evidence to show that the average age of teachers in a school is an

\footnotetext{
${ }^{4}$ As a consequence, public spending on education has risen to the top of the political agenda in Italy. See https://www.europeanceo.com/finance/italys-myopic-budget-is-harming-the-education-sector-heres-how/

${ }^{5}$ More broadly links between a workplace's performance and its age distribution are contested, with the latest research suggesting that, across the economy at large, older workers do not affect workplace performance (Bryson et al., forthcoming). However, the hypothesis here is specific to the context of Italian secondary schools, the nature of human capital acquisition in Italian schools and the procedures used to allocate teachers based on seniority.
} 
increasing function of the proximity of the school to an urban centre and to the population in the school's vicinity. The intuition behind these instruments is that as teachers age they switch to more urban schools due to the non-wage utility they derive from such schools. Schools' distance from urban centres and population can reasonably be excluded from estimates of pupil attainment because they can only affect attainment via teacher sorting.

When treated as exogenous, teacher average age is not associated with school performance in examinations. However, the instrumental variables estimates reveal a negative and statistically significant impact of older teachers on permanent contracts, consistent with older teachers having poorer pedagogical skills, lower motivation or poorer technical skills. We suspect the OLS estimates reveal no effect because older teachers exercise their options to select into schools that are better along dimensions we are unable to observe, imparting an upward bias to the coefficient on the teacher age distribution in the school. The instrument accounts for this non-random sorting, revealing the underlying negative association between teacher age and school level pupil attainment. This age effect can be separated from seniority in the school, which is itself positively and statistically associated with school performance, as one might expect when there are positive pupil returns to teachers' school specific human capital. At the same time, greater use of fixed-term contract teachers is negatively correlated with pupil attainment at a school.

The remainder of the paper is structured as follows. Section Two provides institutional background on the nature of the secondary education system in Italy and reviews the literature on the importance of schools and teachers for pupil attainment in Italy. Section Three describes our data and presents our estimation strategy. Section Four presents results. Section Five concludes and discusses the policy implications.

\section{INSTITUTIONAL BACKGROUND AND LITERATURE}

Since the 1990s the Italian public school system has been subject to substantial budget cuts, as have other areas of public expenditure. Official data from ISTAT (the Italian national statistical office) shows that public spending in this sector fell from 5.4\% of GDP in 1992 to $4.4 \%$ in 2000 and has continued to fall, reaching $3.8 \%$ in 2017 . These data refer to the whole system encompassing primary, secondary and tertiary education as well as vocational programs. Focusing exclusively on 
secondary education there has been a similar but less severe decline: the spending on secondary schools has fallen from $2.13 \%$ of GDP in 1997 to $1.73 \%$ in 2017.6

Since the largest expenditure in secondary education is teachers' salaries and pensions, it is perhaps no surprise to find that the fall in secondary school expenditure has been accompanied by a reduction in the total number of secondary school teachers (Figure 1). According to ISTAT, there were 326,000 secondary school teachers in 1992. This had fallen to 300,000 in 2000 and reached an all-time low of 248,000 in 2013 . After that year, the number started to rise a little.

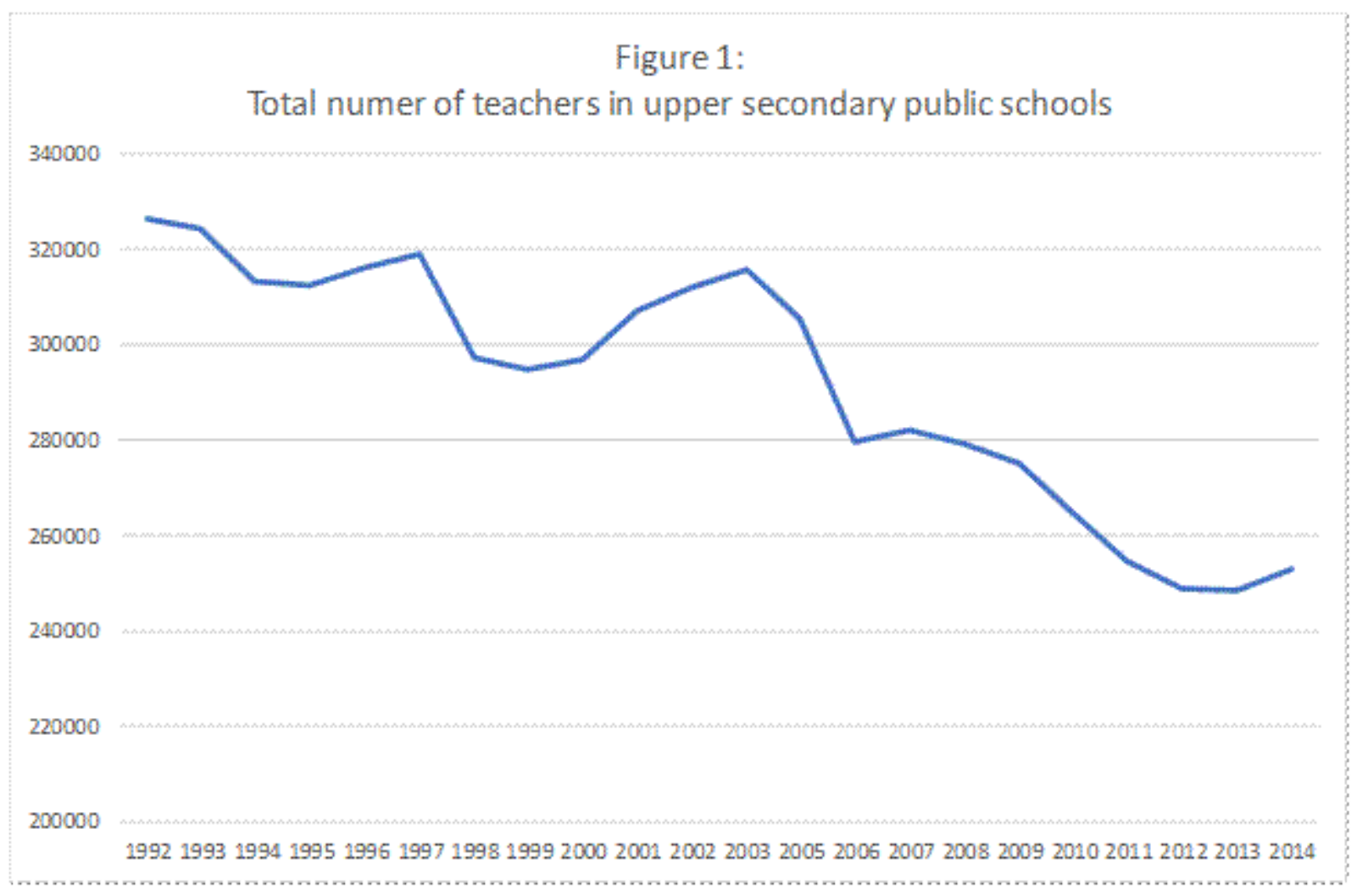

In same time-span there has also been a moderate reduction in the number of students: according to ISTAT the number of pupils enrolled in upper secondary school was 2.89 million in 1992 (the alltime high for Italy), falling to 2.57 million in 2000 before climbing back to 2.65 million in 2013 . However, the fall in teacher numbers far outstrips the fall in pupil numbers, so that the teacher

\footnotetext{
${ }^{6}$ The source is the OECD statistics and the Government expenditure by function (COFOG) (OECD, 2020).
} 
resource per pupil has fallen (the student per teacher ratio increased from 8.8 in 1992 to 9.9 in 2013).

There has also been a shift in the composition of teacher contracts, with an increasing proportion of teachers being employed on fixed-term contracts. Data on the number of teachers with permanent contracts is only available for recent years, but the data from the education ministry reports that the number of teachers on permanent contracts has fallen from 231,000 in 2006 to 211,000 in 2011 . This fall in the number of teachers was not achieved with firing or lay-offs but rather with a severe slowdown in the replacement of teachers reaching retirement. As a consequence, there has been a progressive ageing of teachers (see below).

\section{Hiring and allocation of teachers}

To understand how the Italian school system works it is important to describe the key features of the procedure to hire and allocate teachers. Below we discuss how wages are determined, how teachers are hired, and how positions are assigned.

Teachers' wages are fixed centrally. A national contract covers all teachers on permanent contracts in the public sector. It determines the actual amount teachers earn based only on time in the profession. Schools are unable to depart from these centrally-set rates, even where there is an excess or shortage of labour at the aggregate or local level. Non-permanent teachers have the same pay scale as permanent teachers but they do not benefit from any seniority.

To become a teacher with a permanent contract it is first necessary to pass a national examination: as a result of each of these examinations a pre-set number of applicants are eligible to be hired as permanent teachers. Passing the examination makes a teacher eligible for a permanent position, but eligible teachers are only able to move into permanent positions when schools have vacant positions. In the last twenty years, national governments have limited these examinations so that the numbers of new teachers eligible for permanent contracts has fallen. Thus, in practice, the opportunities to become a permanent teacher have been quite rare.

When a permanent position in a school becomes vacant (usually because someone retires or moves elsewhere) other teachers can apply for it. Teachers eligible for permanent contracts have priority in applying. In a given year, teachers must select a single province (that can be different from the one where they are currently working in) and they will then be able to apply only to positions that 
open within that province. The position is then assigned on the basis of a ranking (which is mostly based on seniority) made among all the applicants. ${ }^{7}$

Any positions that are left vacant by applicants eligible to be hired into permanent positions are then offered to the rest of the applicants and are thus offered as fixed term contracts.

The appointment of teachers to fixed-term posts operates quite differently. To be eligible for fixed term positions it is necessary to register with one (and only one) provincial school office. Anyone with a tertiary degree can register. Only registered people can then apply for available fixed-term teaching positions and registrations usually open once every three years. When registrations close, an overall ranking is made among all registered individuals in a given province for a given subject and the highest ranked candidates are able to choose from the available fixed-term contract slots available.

These mechanisms, together with the reduction in the number of teachers, have produced at least two effects. The first one is clearly observable and consists in an increase in the average age of teachers. The mean age of teachers grew from 46 years old in 1998 to 49 in 2003 and reached 53 in 2015 (these data are for upper secondary teachers and come from Ministero dell'istruzione 1999, 2004 and OECD, 2017). The second effect is the growing importance of teacher self-selection in determining where teachers end up teaching. This is because the seniority rules mean teachers rise through the rankings that determine which posts they can choose as they age.

\section{Recent Literature}

School quality is an important determinant of pupil attainment in Italy (Brunello and Checchi, 2005), though precisely how much school effects matter depends on how they interact with other inputs, most notably parents (Brunello and Checchi, 2005). School effects also vary according to which part of the country one lives in. Agasisti and Vittadini (2012) note that between-school variance in pupil attainment is much greater in Southern Italy than it is in Northern Italy. In subsequent work Agasisti et al. (2017) find school effects differ in terms of magnitude and direction across Northern, Central and Southern Italy. ${ }^{8}$

\footnotetext{
${ }^{7}$ The actual rules used in these assignments are rather complex (see https://www.miur.gov.it/graduatorie-di-istituto). Usually transfers within municipality have precedence over transfers within province that, in turn, have precedence over transfers from outside a given province. Outside this "geographical" precedence, the ranking is strongly based on seniority.

${ }^{8}$ The magnitude of between-school effects reported by Agasisti et al. (2017, Figure 1 ) is of a similar order to that found in England, for example (Wilkinson et al., 2018).
} 
Although the role of school effects in accounting for variance in pupil attainment is welldocumented in Italy, identifying the source of the variance has not proven straightforward. For example, school curricula and teaching methods are heavily regulated so that schools should not vary greatly in what they teach nor how they teach it. Early studies pointed to a role for student selection but in their study Agasisti and Vittadini (2012) find no role for student sorting by socioeconomic status. Other studies point to variance in resources available to schools. For instance, Brunello and Checchi (2005) show that falling pupil-teacher ratios played an important role in improved educational attainment between the end of the Second World War and the late 1980s. An example of a study that addresses the importance of school staff is Di Liberto et al. (2015). Their analysis focuses on the managerial practices implemented by the headmaster and finds that their implementation improves the performance of students (in terms of standard maths tests). They find that leadership capacity and monitoring activities of school processes are particularly relevant. ${ }^{9}$ Little attention has been given to the role played by variance in teacher quality. This may be because, as Agasisti et al. (2017: 158) note: "teachers are not hired by the single schools, but are selected through a national-level procedure, and assigned to schools by the Ministry of Education (under the presumption that the teacher differences do not play a role in influencing school results)". This presumption may be mistaken if, as we have argued above, teacher quality or teacher motivation are negatively correlated with teachers' age, and teachers with greater seniority are better able to select high-amenity schools. There is some evidence to support the importance of teacher career satisfaction in pupils' reading attainment in Italy: in their analysis of the 2006 Progress in International Reading Literacy Study (PIRLS) Alivernini et al. (2010) found teacher career satisfaction was the only teacher/school level variable associated with reading attainment among Italian fourth-grade students. ${ }^{10}$ Boarini (2009) notes that "compulsory school education in Italy produces poor results in terms of 15-year olds' performance on PISA tests compared with other OECD countries, despite a relatively high level of expenditure", and speculates that one cause of the problem is "the motivation of Italian teachers [which] seems to be relatively weak" (p. 32) which, in turn, may reflect the fact that "Italian teachers are less well paid than their average OECD counterpart" (p. 33). He also notes that the average age of teachers in Italy is high compared to

\footnotetext{
${ }^{9}$ Other studies have also pointed to the importance of management practices in explaining school-level differences in pupil attainment. See, for example, Bryson et al. (2020).

${ }^{10}$ The study captured teachers' satisfaction with their current position and career choice as a whole. Factors that were not significantly associated with pupil reading attainment included school resources, the principal's perception of school climate, the principal's perception of school safety, and home educational resources.
} 
the OECD average, and that "formal professional development is relatively limited in Italy, being neither compulsory nor required for promotion. Teachers have to bear the cost of training, including leave, since there is no statutory research or training leave" (p. 34). This, together with the fact that wage compression is "particularly strong" (p.33) in Italy may result in older teachers who are both less motivated and less well-trained than they might be in other OECD countries.

We exploit the idea that in Italy teachers with more seniority will end-up in better schools generating endogeneity in the teacher age variable. Barbieri et al. (2011) observe this in their study, arguing that, in Italy, "teachers are likely to be queuing up, on the basis of seniority, in order to leave schools with high concentrations of disadvantaged and minority students" (p. 1431). They go on to suggest that "teachers seem to try to avoid schools located in a context with a high illiteracy rate, a high proportion of people employed in agriculture, and a low employment rate. Furthermore, a high share of disabled students, foreign born students and students enrolled in the first year in a school having had to repeat one or more years' in their previous school career make a school less attractive to teachers." (p. 1442).

\section{DATA DESCRIPTION}

The data we use in our analysis come from the Scuola in chiaro, an on-line service offered by the ministry of education providing information on all Italian schools (www.cercalatuascuola.it). We confine our data analysis to public upper secondary schools in the Tuscany region $(N=300)$.

The dataset contains information related to the schools in the year 2017/18 (their orientation, location at the municipality level, total number of pupils and average class size), to some (aggregate) characteristics of their pupils (entrance mark, graduation mark and the share of non-native students) and staff (total number of teachers, gender composition, average age of permanent teachers, average experience within the same school of teachers and headmaster, share of nonpermanent teachers). Descriptive statistics are provided in Appendix Table A. It is worth noting that some schools share the same headmaster, something we account for in our estimation with clustered standard errors.

The variable we use to measure school performance is the average graduation mark of students: it is the average within each single school of the mark (from 60 to 100) at the final exam that allows students to graduate and obtain their degree. We run some robustness tests to two alternative ordinal measures of school performance based on head teacher self-assessments: they still come from the Scuola in Chiaro service and the first measure refers to the self-assessment of whether 
"the students pursue regularly their study path and conclude it with satisfying exam result" and the second measure refers to the self-assessment of how the students performed in the INVALSI standardized national students' evaluation ${ }^{11}$. Whilst of potential value as a robustness check they are inferior to graduation marks since we have no information on the way in which head teachers rate their schools. In addition, in the cases where a single head teacher performs the role for multiple schools, the head teacher provides a single performance evaluation for the group of schools, introducing measurement error which we avoid in the case of average graduation marks for each school.

Before exploring some of our data, it is worth explaining how the Italian upper secondary education is organized since this informs the school classification we adopted in our analysis. Upper secondary schools are divided in three main orientations: i) lyceum schools offering a more generalist approach, ii) technical schools that offer more applied skills and knowledge and iii) vocational schools that focus mostly on vocational education. These three orientations are further characterized by specific paths that can differ substantially. Within the lyceum group there are 6 different paths: science, classical studies, linguistics, figurative arts, socio-pedagogical studies and music. The first two paths have a more generalist approach and are thus different from the rest that focus more narrowly on specific disciplines.

In our analysis we classify schools according to these orientations and split the lyceum orientation in two to account for the six paths within that group. We thus end up with four categories of school: i) Classical and Scientific Lyceums, ii) Other Lyceums, iii) Technical Schools and iv) Vocational Schools.

When considering these categories, it is often assumed that, on average, the "best" students select the classical and scientific lyceums and less-gifted students pick the vocational schools while the rest of students pick the other two categories. We confirm this is the case with our data in row 1 of Table 1 which shows the mean marks for newly enrolled students (in theory the mark of each student can vary from 6 to 10) by school type in each of the four school categories: there is a strong correlation between the orientation of the school and the quality of entrants indicating that better students are attracted by classic and scientific lyceums and the less-gifted academic students enter

${ }^{11}$ The INVALSI evaluation are the tests used in Italy for the Programme for International Student Assessment (PISA). 
vocational schools. Row 2 shows the same ordering of schools obtains in the case of average graduation marks.

Table 1: Mean Pupil Attainment by School Type

\begin{tabular}{|l|l|l|l|l|}
\hline & $\begin{array}{l}\text { Classic or Scientific } \\
\text { Lyceums }\end{array}$ & Other Lyceums & $\begin{array}{l}\text { Technical } \\
\text { Schools }\end{array}$ & $\begin{array}{l}\text { Vocational } \\
\text { Schools }\end{array}$ \\
\hline Average mark of entrants & 8.36 & 7.55 & 7.16 & 6.65 \\
\hline Average graduation mark & 79.39 & 78.09 & 75.35 & 74.47 \\
\hline
\end{tabular}

This classification of school orientations is also important in terms of some relevant characteristics of teachers. Table 2 reports the average age of permanent teachers and the average share of nonpermanent teachers across the four school types. Teachers are a little older in lyceums while younger and non-permanent teachers are more likely to be found in the other types of school. This is likely to be the effect of the job allocation mechanism: permanent and senior teachers choose first and, with time, they self-select into schools that they judge to be better.

Table 2: Mean Teacher Characteristics by School Type

\begin{tabular}{|l|l|l|l|l|}
\hline & $\begin{array}{l}\text { Classic or Scientific } \\
\text { Lyceums }\end{array}$ & Other Lyceums & $\begin{array}{l}\text { Technical } \\
\text { Schools }\end{array}$ & $\begin{array}{l}\text { Vocational } \\
\text { Schools }\end{array}$ \\
\hline $\begin{array}{l}\text { Average age of permanent } \\
\text { teachers }\end{array}$ & 49.55 & 48.66 & 48.42 & 47.11 \\
\hline $\begin{array}{l}\text { Average share of teachers on } \\
\text { fixed-term contracts }\end{array}$ & 0.24 & 0.28 & 0.30 & 0.35 \\
\hline
\end{tabular}

In Table 3 we explore whether there is a relationship between the location of schools and the characteristics of teachers comparing the average age of teachers and the presence of nonpermanent teachers distinguishing between schools located in main towns (defined as the seat of the province) and elsewhere. Older teachers and those on permanent contracts are more likely to be found in main towns, an outcome we have argued is due to the job allocation mechanism with permanent and senior teachers self-selecting towards schools more conveniently located. 
Table 3: Mean Teacher Characteristics by School Location

\begin{tabular}{|l|l|l|}
\hline & Schools in main town & Schools not in main town \\
\hline Average age of permanent teachers & 49.32 & 47.63 \\
\hline Average share of teachers on fixed-term contracts & 0.25 & 0.33 \\
\hline
\end{tabular}

\section{ESTIMATION RESULTS}

We turn now to the regression analyses which examine the determinants of school performance as indicated by pupil attainment. Our dependent variable is the school's average graduation mark in the academic year $2017 / 18$. As a robustness check we run the same analyses for the head-teacher self-assessed pupil attainment based on standardised INVALISI scales. The results, which are presented in the appendix, are essentially the same as those we present for average graduation mark.

The first model we estimate in Table 4 is a simple OLS regression with clustered standard errors to account for some schools having the same head teacher. The model explains around two-thirds of the variance in school-level pupil attainment but it is dominated by the mean attainment of pupils on entering the school. This is strongly statistically significant and positive, as one might expect since it partly captures the quality of pupils on entering the school. Its inclusion means the models are, essentially, school value-added models which are common in the literature (eg. Wilkinson et al., 2018).

Other variables associated with better pupil attainment are the number of support teachers in the school and the longevity of the head teacher. In this OLS model the average age of teachers has a negative sign but it is not statistically significant. However, we suspect that age is endogenous with respect to pupil attainment so that it is correlated with the unobserved quality of schools and students. This is likely since the Italian system allows older teachers to be the first to choose their destination school. It is thus likely that they choose to work in schools that are better, with higher quality (or less troublesome) students: this would produce a positive correlation between unobserved school quality and teacher age biasing upward the effect of the latter.

To account for this source of endogeneity we adopt an instrumental variables (IV) approach allow. As we described earlier, our instruments are the geographical distance from urban centres and population size in the vicinity of the school. We use these in a two-stage least squares estimator to 
identify the causal impact of exposure to older teachers. The intuition behind these instruments is that as teachers age they switch to more urban schools due to the non-wage utility they derive from such schools: the Italian school system appears to be fully consistent with this hypothesis. Schools' distance from urban centres and population can reasonably be excluded from estimates of pupil attainment because they can only affect attainment via teacher sorting conditional on pupil quality on entering the school.

Table 4: Average Graduation Mark, OLS and IV Estimates

\begin{tabular}{|c|c|c|}
\hline & (i) & (ii) \\
\hline & OLS & IV \\
\hline Average age of teachers & $\begin{array}{r}-0.155 \\
(1.55)\end{array}$ & $\begin{array}{c}-0.642 * * \\
(0.25)\end{array}$ \\
\hline Entrance mark of students & $\begin{array}{c}2.969 * * * \\
(0.392)\end{array}$ & $\begin{array}{c}2.94 * * * \\
(0.40)\end{array}$ \\
\hline Students per class & $\begin{array}{c}-0.034 \\
(0.0657)\end{array}$ & $\begin{array}{l}-0.023 \\
(0.07)\end{array}$ \\
\hline Number of students & $\begin{array}{r}0.0004 \\
(0.0004)\end{array}$ & $\begin{array}{r}0.0002 \\
(0.0004)\end{array}$ \\
\hline Share of immigrants students & $\begin{array}{r}0.015 \\
(0.02)\end{array}$ & $\begin{array}{r}0.025 \\
(0.03)\end{array}$ \\
\hline Number of teachers & $\begin{array}{l}-0.005 \\
(0.005)\end{array}$ & $\begin{array}{l}-0.005 \\
(0.005)\end{array}$ \\
\hline Number of support teachers & $\begin{array}{l}0.039 * * * \\
(0.013)\end{array}$ & $\begin{array}{l}0.044 * * * \\
(0.01)\end{array}$ \\
\hline Share of female teachers & $\begin{array}{r}0.00901 \\
(0.0178)\end{array}$ & $\begin{array}{r}0.013 \\
(0.02)\end{array}$ \\
\hline Years of experience of teachers & $\begin{array}{c}0.0361 \\
(0.0709)\end{array}$ & $\begin{array}{l}0.15^{*} \\
(0.9)\end{array}$ \\
\hline Share of fixed term teachers & $\begin{array}{r}-0.583 \\
(0.95)\end{array}$ & $\begin{array}{c}-2.806^{*} \\
(1.18)\end{array}$ \\
\hline $\begin{array}{l}\text { Same headmaster in last five } \\
\text { years }\end{array}$ & $\begin{array}{c}0.521^{*} \\
(0.269)\end{array}$ & $\begin{array}{c}0.533 * \\
(0.28)\end{array}$ \\
\hline Constant & $\begin{array}{c}62.382 * * * \\
\quad(6.70)\end{array}$ & $\begin{array}{l}91.482^{* * *} \\
(15.61)\end{array}$ \\
\hline School type dummies & YES & YES \\
\hline Province dummies & YES & YES \\
\hline$R^{2}$ & 0.65 & 0.62 \\
\hline$N$ & 300 & 300 \\
\hline
\end{tabular}


Results from this IV, using clustered errors to account for some schools having the same head teacher, are reported in column (ii) of Table 4. Having instrumented mean teacher age in the school the coefficient becomes much larger and is statistically significant with a negative sign confirming our hypothesis that older teachers have a negative impact on the performance of students. The increase in the size of the negative coefficient relative to the OLS estimation is likely due to the fact that older teachers chose better schools, thus obscuring the underlying negative causal impact of older teachers. Quantitatively this is a large effect. The mean graduation mark is 76 with a standard deviation of 3.6. This means that an increase in the age of teachers by six years - which is just under the 7-year increase that has occurred over the last 20 years - produces a decrease in the graduation mark by one standard deviation.

Our choice of instruments (distance from main urban centre and population) appears to be appropriate: we report our first stage estimates in Appendix Table B and statistical tests in Table 5. These indicate that our instruments have all the desired characteristics: we can reject the hypothesis of under-identification; we do not find that our instruments are weak and, according to the overidentification test, we cannot reject the hypothesis that they are uncorrelated with the error term.

Given the validity of our instruments, we infer that our IV estimates correct for the endogeneity bias and recover the causal effect of older teachers on pupil attainment.

Table 5: Tests for instrumental variables appropriateness

\begin{tabular}{lc}
\hline Under-identification test (Anderson canon. corr. LM statistic) & 16.304 \\
Chi-sq(2) p-value & 0.000 \\
\hline Weak identification test (F statistic) & 21.581 \\
Stock-Yogo weak ID test critical values: 10\% maximal IV size & 19.93 \\
\hline Overidentification test (Hansen J statistic) & 0.172 \\
Chi-sq(1) p-value & 0.6782 \\
\hline
\end{tabular}

Results from the IV estimation also display a few more differences from the OLS: the share of fixed term teachers is negatively associated with pupil attainment while teachers' experience in the current school has a positive effect, though its effect is only on the margins of statistical significance. 
This latter effect shows that while age is detrimental to performance, school-specific experience is not.

To check for robustness, we reran our estimates for an alternative measure of pupil attainment, namely the self-assessed score. The results, presented in Appendix C, are similar to our main findings.

\section{DISCUSSION AND CONCLUSION}

In this paper we have argued that the system by which teachers are allocated to secondary schools in Italy, whilst appearing benign, actually operates to the detriment of pupils in those schools with high amenity value to teachers, namely those in urban locations with larger populations. This happens because the system means teachers sort into the most desirable schools later in their careers by virtue of their age-based seniority. Although this is not apparent if one treats teacher mean age in schools as exogenous, it emerges once we account for endogenous selection. The effect is large: a six-year increase in the average age of teachers (roughly similar to the increase that has occurred in the last 20 years) leads to a one standard deviation reduction in the mean graduation mark.

Older teachers may be detrimental to pupil attainment because they are less productive than those from younger cohorts, either because their skills deplete with time due to a lack of on-the-job training; they lack the skills-set of their younger counterparts who benefit from recent innovations in teacher training; or because they lack the motivation to strive for teaching excellence (something younger teachers must do to secure permanent posts). We are unable to test between these potential mechanisms with the data at our disposal, but this would be a fruitful avenue for future research.

Nevertheless, our findings have important implications for education policy and practice in Italy since, for the first time, they point to unintended negative consequences of the system by which teacher allocation occurs in secondary schools. This problem is compounded by the practice in the last few decades, driven by budget constraints, which has limited opportunities for new cohorts to enter teaching. This happens because the examinations teachers must pass to be eligible for permanent contracts are offered less regularly than they used to be. It seems sensible to review this practice, together with seniority-based access to permanent contracts, in the hope that a new cohort of teachers can improve pupil attainment in Italian schools. 


\section{References}

Agasisti, T., leva, F. and Paganoni, A. M. (2017) "Heterogeneity, school-effects and the North/South achievement gap in Italian secondary education: evidence from a three-level mixed model", Statistical Methods Applied, 26: 157-180

Agasisti, T. and Vittadini, G. (2012) "Regional Economic Disparities as Determinants of Students' Achievement in Italy", Research in Applied Economics, 4, 1: 33-53

Aliverini, F., Manganelli, S. Vinci, E. And Di Leo, I. (2010) "An evaluation of factors influencing reading literacy across Italian 4th grade students", US-China Education Review, 7, 5: 88-93

Barbieri, G., Rossetti, C. and Sestito, P. (2011) "The determinants of teacher mobility: Evidence using Italian teachers' transfer applications", Economics of Education Review, 30, 6: 1430-1444

Boarini, R. (2009) "Towards better schools and more equal opportunities for learning in Italy", Economics Department Working Paper No. 727, OECD

Brunello, G. and Checchi, D. (2005) "School quality and family background in Italy", Economics of Education Review, 24: 563-577

Bryson, A., Forth, J., Gray, H. and Stokes, L. (forthcoming) "Does Employing Older Workers Affect Workplace Performance?", Industrial Relations: A Journal of Economy and Society

Bryson, A., Stokes, L. and Wilkinson, D. (2020) "Can HRM Improve Schools' Performance?", Labour DOI: $10.1111 /$ labr.12178

Di Liberto, A., Schivardi, F. and Sulis, G. (2015) "Managerial practices and student performance," Economic Policy, 30, 84: 683-728.

Masci, C., leva, F., Agasisti, T. and Paganoni, A. M. (2016) "Does class size matter more than school? Evidence from a multilevel statistical analysis on Italian junior secondary school students", SocioEconomic Planning Sciences, 54: 47-57

Ministero dell'istruzione (1999), La scuola statale: sintesi dei dati anno scolastico 1998/1999.

Ministero dell'istruzione (2008), La scuola statale: sintesi dei dati anno scolastico 2007/2008.

OECD (2017), "D5.1. Average age of teachers by education level (2015)", in The Learning Environment and Organisation of Schools, OECD Publishing, Paris 
OECD (2020) "Data warehouse", OECD.Stat (database), https://doi.org/10.1787/data-00900en (accessed on 04 September 2020).

Wilkinson, D., Bryson, A. and Stokes, L. (2018) "Assessing the variance in pupil attainment: how important is the school attended?", National Institute Economic Review, No. 243, R4-R16 
APPENDIX A: descriptive statistics and description of variables

\begin{tabular}{|c|c|c|c|c|c|}
\hline & Mean & Std. dev. & Min & Max & Description \\
\hline $\begin{array}{l}\text { Average graduation } \\
\text { mark }\end{array}$ & 76.497 & 3.5964 & 68.50 & 86.19 & $\begin{array}{l}\text { Average mark within a school of the } \\
\text { final mark that each student received } \\
\text { (from } 60 \text { to } 100 \text { cum laude) }\end{array}$ \\
\hline $\begin{array}{l}\text { Average age of } \\
\text { teachers }\end{array}$ & 48.346 & 2.7597 & 41.96 & 54.84 & $\begin{array}{l}\text { Average age of permanent teachers } \\
\text { within a school }\end{array}$ \\
\hline $\begin{array}{l}\text { Entrance mark of } \\
\text { students }\end{array}$ & 7.4098 & .85136 & 6.2 & 9.81 & $\begin{array}{l}\text { Average mark within a school of the } \\
\text { final mark that each student received in } \\
\text { the previous cycle (from } 6 \text { to } 10 \text { ) }\end{array}$ \\
\hline Students per class & 19.720 & 3.2799 & 2 & 28.11 & Average number of student per class \\
\hline Number of students & 479.48 & 379.70 & 6 & 1988 & Total number of students \\
\hline $\begin{array}{l}\text { Share of immigrants } \\
\text { students }\end{array}$ & 11.494 & 8.6931 & 0 & 43.47 & Share of students that was foreign born \\
\hline Number of teachers & 123.21 & 45.361 & 10 & 277 & Total number of teachers \\
\hline $\begin{array}{l}\text { Number of support } \\
\text { teachers }\end{array}$ & 22.941 & 15.964 & 0 & 67 & $\begin{array}{l}\text { Total number of teachers that are } \\
\text { assigned to students with special needs }\end{array}$ \\
\hline $\begin{array}{l}\text { Share of female } \\
\text { teachers }\end{array}$ & 65.655 & 8.9914 & 43.45 & 87.097 & Share of teachers that are female \\
\hline $\begin{array}{l}\text { Same headmaster in } \\
\text { last five years }\end{array}$ & .3770 & .48544 & 0 & 1 & $\begin{array}{l}\text { Dummy that signals whether the } \\
\text { headmaster was in charge in the given } \\
\text { school for at least } 5 \text { years }\end{array}$ \\
\hline $\begin{array}{l}\text { Years of experience } \\
\text { of teachers }\end{array}$ & 9.503174 & 2.5025 & 2.03 & 16.6485 & $\begin{array}{l}\text { Average number of years that teachers } \\
\text { stayed in the given school }\end{array}$ \\
\hline $\begin{array}{l}\text { Share of fixed term } \\
\text { teachers }\end{array}$ & .297741 & .119570 & .0517 & .8 & $\begin{array}{l}\text { Share of teachers whose position is not } \\
\text { permanent and will last one year or } \\
\text { less. }\end{array}$ \\
\hline
\end{tabular}


APPENDIX B: First stage regression for the average age of teachers

Distance from town

Population (in thousands)

Entrance mark of students

Students per class

Number of students

Share of immigrants students

Number of teachers

Number of support teachers

Share of female teachers

Years of experience of teachers

Share of fixed term teachers

Same headmaster in last five years

Constant
$-0.0158 * *$

(0.00637)

$0.419 * * *$

(0.134)

0.055

(0.235)

0.003

(0.041)

$-0.0007 * * *$

(0.0002)

0.016

(0.019)

0.0026

(0.0046)

$-0.0033$

(0.0121)

0.0035

(0.0131)

$0.307 * * *$

(0.05)

$-3.741 * * *$

(0.404)

0.162

(0.225)

$56.84 * * *$

(2.395)

YES

YES

0.817

$N \quad 300$

Clustered standard errors in parentheses. Significance level: *** $1 \% ; * * 5 \%$; *10\% 
APPENDIX C: Self-assessed measures of students' performance, IV Estimates

\begin{tabular}{|c|c|c|}
\hline & $\begin{array}{l}\text { Self-assessment of } \\
\text { overall student results }\end{array}$ & $\begin{array}{l}\text { Self-assessment of students' } \\
\text { results in standardized tests }\end{array}$ \\
\hline Average age of teachers & $\begin{array}{c}-0.413 * * \\
(0.165)\end{array}$ & $\begin{array}{c}-0.428 * * * \\
(0.139)\end{array}$ \\
\hline Entrance mark of students & $\begin{array}{r}0.268 \\
(0.180)\end{array}$ & $\begin{array}{l}0.315^{* *} \\
(0.142)\end{array}$ \\
\hline Students per class & $\begin{array}{r}0.00725 \\
(0.0283)\end{array}$ & $\begin{array}{l}-0.0254 \\
(0.0304)\end{array}$ \\
\hline Number of students & $\begin{array}{l}-0.000201 \\
(0.000221)\end{array}$ & $\begin{array}{l}-0.000178 \\
(0.000224)\end{array}$ \\
\hline Share of immigrants students & $\begin{array}{l}-0.0104 \\
(0.0144)\end{array}$ & $\begin{array}{c}-0.00490 \\
(0.0116)\end{array}$ \\
\hline Number of teachers & $\begin{array}{c}0.00340 \\
(0.00367)\end{array}$ & $\begin{array}{r}0.00125 \\
(0.00326)\end{array}$ \\
\hline Number of support teachers & $\begin{array}{l}-0.0158^{*} \\
(0.00958)\end{array}$ & $\begin{array}{c}-0.0103 \\
(0.00855)\end{array}$ \\
\hline Share of female teachers & $\begin{array}{r}0.0136 \\
(0.0116)\end{array}$ & $\begin{array}{l}-0.00727 \\
(0.0104)\end{array}$ \\
\hline Years of experience of teachers & $\begin{array}{c}0.0887 * \\
(0.0529)\end{array}$ & $\begin{array}{l}0.152 * * * \\
(0.0462)\end{array}$ \\
\hline Share of fixed term teachers & $\begin{array}{l}-1.694 * * \\
(0.742)\end{array}$ & $\begin{array}{c}-2.348 * * * \\
(0.663)\end{array}$ \\
\hline $\begin{array}{l}\text { Same headmaster in last five } \\
\text { years }\end{array}$ & $\begin{array}{r}0.208 \\
(0.165)\end{array}$ & $\begin{array}{c}0.0175 \\
(0.160)\end{array}$ \\
\hline Constant & $\begin{array}{l}26.78 * * * \\
(9.963)\end{array}$ & $\begin{array}{l}29.71 * * * \\
(8.149)\end{array}$ \\
\hline School type dummies & YES & YES \\
\hline Province dummies & YES & YES \\
\hline$N$ & 297 & 295 \\
\hline
\end{tabular}

